\title{
Effects of drying methods on the physicochemical properties of powder made from different parts of pumpkin
}

\author{
${ }^{1}$ Lim, J., ${ }^{1}$ Taip, F.S., ${ }^{1}$ Ab Aziz, N., ${ }^{1}$ Ibrahim, M.N. and ${ }^{2}$ How. M.S. \\ ${ }^{1}$ Department of Process and Food Engineering , Faculty of Engineering, University Putra Malaysia, 43400 \\ Serdang, Selangor. \\ ${ }^{2}$ Department of Chemical and Bioprocess Engineering, School of Food and Advanced Technology, Massey \\ University, Palmerston North, New Zealand.
}

\begin{abstract}
Article history:
Received: 29 September 2020

Received in revised form: 4

November 2020

Accepted: 24 March 2021

Available Online: 28 March

2021
\end{abstract}

Keywords:

Rapid hot air drying,

Pumpkin powder,

Freeze-drying

DOI:

https://doi.org/10.26656/fr.2017.5(S1).058

\begin{abstract}
Pumpkin (Cucurbita sp.) is a widely consumed fruit as it has high carotenoid content and medicinal value, but has a relatively short shelf life and prone to microbial spoilage. Various drying techniques have been introduced to the industry to preserve pumpkinbased products. During the drying process, products are prone to serious decay caused by changes in temperature, thus affecting the physical or chemical properties of the product. The objective of this study was to determine the effects of different drying methods on the physical properties and proximate composition of pumpkin powder produced from different parts of the fruit. Samples were made using unpeeled pumpkin and parts of the fruit, i.e. skin, flesh and seed and were dried using different drying methods, i.e. oven $\left(80^{\circ}\right.$ C), rapid hot air oven $\left(80^{\circ} \mathrm{C}\right)$ and freeze dryer $\left(-110^{\circ} \mathrm{C}\right)$. The dried samples were then milled and sieved at approximately $250 \mu \mathrm{m}$ and $710 \mu \mathrm{m}$ in diameter. Different drying methods had a significant influence on the physical and chemical properties of the samples $(\mathrm{p}<0.05)$. Rapid hot air drying showed a promising impact on the production of pumpkin powder resulting in powder with a moisture content of 5.61-6.89\%, particle size of $122.98-256.46 \mu \mathrm{m}$, and density of $304.80-724.69 \mathrm{~kg} / \mathrm{m}^{3}$. These results were better than freeze-dried powders. Proximate composition values of samples dried using rapid hot air were also found to be better than oven-dried powder with a protein content of 9.86$31.54 \%$ and fat content of $3.88-34.93 \%$. In conclusion, rapid hot air-dried powder showed the best quality in terms of physical properties and proximate composition.
\end{abstract}

\section{Introduction}

Cucurbita moschata, Cucurbita pepo and Cucurbita maxima are three of the most commonly grown species of pumpkin. In Malaysia, Cucurbita moschata, locally known as "labu manis" and Cucurbita moschata Duchesne, also known as "labu loceng" are the most commonly cultivated varieties (Norshazila et al., 2014).

Pumpkin has received increasing interest because of its nutritional and health beneficial values. Conventionally, pumpkin skin and seed are considered waste, but they are beneficial for health. Compared to the skin and seed, pumpkin flesh is the most consumed part of the fruit. Pumpkin flesh contains a lot of beta-carotene which is believed to have a role in preventing cancer and coronary heart disease (See et al., 2007). Pumpkin skin is not as popular as its flesh and seed but it is reported to be rich in fibre and pectin component (Jun et al., 2006;
Norfezah et al., 2010) which has the potential to reduce blood cholesterol and glucose and promote the growth of intestinal bacteria (Lee et al., 1997). Pumpkin seed also contains healthy fats such as omega 3 and omega 6 fatty acids which can reduce the serum in cholesterol and prevent chronic disease for an instance, colon cancer (Kim et al., 2012).

Pumpkins are highly sensitive to microbial spoilage, even at refrigerated condition, hence, must be frozen or dried (Doymaz, 2007). Drying is an ancient technique for the preservation of fruits and vegetables and it involves the removal of water from the product to provide microbiological safety. Oven drying is a common drying method for fresh plant materials while freeze-drying is another renowned drying method for a better quality of dried products (Henriques et al., 2012). Rapid hot air drying utilizes high airflow to expedite the drying process. The effects of a specific drying method on the 
preservation of raw quality cannot be predicted, as they are dependent on the type of chemical compounds present and the type of plant (Lin et al., 2012). In this research, the effects of different drying methods on the physicochemical properties of various parts of pumpkin fruit will be investigated.

\section{Materials and nethods}

\subsection{Sample preparation}

Ripe pumpkin (Cucurbita maxima) fruits were collected from Long Ei Plantation Sdn Bhd. The pumpkin fruits were washed and peeled, and the seeds were removed. The flesh and unpeeled samples were cut into slices $(3.0 \mathrm{~cm} \times 1.5 \mathrm{~cm} \times 0.2 \mathrm{~cm})$, while the skin was cut into rectangular shapes $(2.0 \mathrm{~cm} \times 1.0 \mathrm{~cm})$. Subsequently, the seeds were washed and drained.

\subsection{Drying}

Different parts of pumpkin were dried using three methods; oven drying at $80^{\circ} \mathrm{C}$ for $30 \mathrm{hrs}$ (skin, flesh and unpeeled part) and $80^{\circ} \mathrm{C}$ for $15 \mathrm{hrs}$ (seed part) using Memmert Type U40, West Germany oven dryer; freezedrying at $-110^{\circ} \mathrm{C}$ and $0.01 \mathrm{~Pa}$ pressure for $96 \mathrm{hrs}$ using laboratory vacuum freeze dryer (BEW HAY/SB4, United Kingdom); and rapid hot air drying at $80^{\circ} \mathrm{C}$ for 2 hrs 45 mins (skin, flesh and unpeeled part) and $80^{\circ} \mathrm{C} 1$ hour 15 mins (seed part) using air fryer (Philips HD 9220/20, Japan). Before freeze-drying, samples were placed in a deep freezer at $-20^{\circ} \mathrm{C}$ for $48 \mathrm{hrs}$ to reduce the temperature of the samples. All drying methods were conducted until the samples reached a moisture content of below $10 \%$, which is the recommended value for powder production (Saohin et al., 2007). The dried samples were milled, and the powder was then sieved with sizes of $250 \mu \mathrm{m}$ (skin, flesh and unpeeled part) and $710 \mu \mathrm{m}$ (seed part) respectively.

\subsection{Analysis of the powder}

Moisture content (\%) was determined using the oven drying method (AOAC, 2000). Two to five grams of the sample was weighed and dried in an oven at $105^{\circ} \mathrm{C}$ for $24 \mathrm{hrs}$ in triplicate. The water activity was measured using a laboratory water activity meter (FA-ST/lab; GDX Instrumentation Scientifique, France) adapted from Tze et al. (2012). Particle size analysis was conducted by measuring the particle size of the $500 \mathrm{mg}$ pumpkin powder sample, using a particle size analyser (Amidon et al., 2009). Bulk density was measured according to Şahin-Nadeem et al. (2013) method. Two grams of pumpkin powder was weighed and poured into a $10 \mathrm{ml}$ cylinder. The volume occupied by the $2.0 \mathrm{~g}$ of pumpkin powder was then used to calculate the bulk density. The bulk density of the sample was defined as the ratio of the mass and volume of the powder.

The flowability of the powders was evaluated in terms of the Carr index (CI) as used by Jinapong et al. (2008). The CI was calculated from the bulk and tapped densities of the powder using the formula as shown below;

$$
\text { Carr Index }=\left(\frac{\rho_{t}-\rho_{b}}{\rho_{t}}\right) \times 100
$$

where $\rho_{b}$ the powder is tapped density and $\rho_{t}$ is the powder bulk density.

The colour of the pumpkin powder samples made from different parts of the fruit was measured by using a colour reader (CR-10; Konica Minolta Sensing America's Ltd., Ramsey, NJ, USA). The lightness ( $\left.\mathrm{L}^{*}\right)$, redness $\left(\mathrm{a}^{*}\right)$ and blueness $\left(\mathrm{b}^{*}\right)$ were measured and the colour change was calculated to identify the difference between two colours in an $\mathrm{L}^{*} \mathrm{a}^{*} \mathrm{~b}^{*}$ colour space. The formula used for the total colour change calculation is shown below:

$$
\Delta \mathrm{E}=\sqrt{\left(L_{0}-L\right)^{2}+\left(a_{0}-a\right)^{2}+\left(b_{0}-b\right)^{2}}
$$

where $\Delta \mathrm{E}$ is the total colour change, $a$ is the redness and $b$ is the blueness.

The proximate composition such as moisture content, crude protein, crude fat, crude fibre and ash was evaluated per AOAC standards, (2000). Moisture content testing was conducted using an oven set at $105^{\circ} \mathrm{C}$ for a duration of $24 \mathrm{hrs}$ while protein content $(\% \mathrm{~N} \times 6.25)$ was determined by using the Kjeldahl method. The sample's crude fat content analysis was carried out based on Soxhlet Extraction Method utilizing petroleum ether at $80^{\circ} \mathrm{C}$. Ash content was measured by conducting the dry ashing procedure while the sample's crude fibre content was obtained by performing testing using AOAC procedures, (2000). Carbohydrate content was determined by difference. All analyses were carried out in triplicates.

\subsection{Statistical analysis}

The data obtained were analysed by a one-way ANOVA followed by Duncan's multiple range test using SAS 9.3 TS L1M2 (SAS, 2014) and one-factor analysis was conducted on the effects of drying methods on the pumpkin powder. Results are considered significant if the p-value was less than 0.05. All measurements were performed in triplicates and the mean value and standard deviations were calculated. 


\section{Results and discussion}

3.1 Effects of different drying methods on physicochemical properties of powder

\subsubsection{Moisture content}

Different drying methods show significant effects on the powder's moisture properties $(\mathrm{p}<0.05)$. The freezedried pumpkin powder had the highest moisture content (6.04-7.89\%), followed by rapid hot air-dried (5.61$6.89 \%$ ) and oven-dried pumpkin powder (5.42-6.69\%). As expected, the moisture content decreased with increased drying time (Nawirska et al., 2009). Throughout the drying process, oven-dried samples were exposed to heat for a longer time (15 hrs to $30 \mathrm{hrs})$, leading to the lowest moisture content in the pumpkin powder samples among all drying methods. Oven-dried pumpkin powder samples showed the highest percentage of moisture loss (28.19-82.68\%) compared to freezedried pumpkin powder with the lowest percentage of moisture loss (27.68-81.44\%). The lowest water activity was observed in oven-dried powder (0.306-0.385) (Table 1). Rapid hot air-dried pumpkin powder resulted in lower water activity than freeze-dried pumpkin powder but higher when compared to the oven-dried samples (Table $1)$. The results were corroborated with the works of Intipunya and Bhandari, (2010), which reported that higher moisture content leads to higher water activity in manufactured products.

Powder made from the seeds had the lowest moisture content (5.42-6.04\%) and lowest water activity (0.3060.421 ), while the powder made from the flesh showed the highest moisture content (6.69-7.89\%) and highest water activity (0.385-0.496) across all drying methods. The observed trend is hypothesised to be caused by the nutritional values of the pumpkin containing high levels of nutrients such as protein, oil and fibre. The hypothesis is supported by Kim et al. (2012) which reported that fresh pumpkin seeds contain $52.43 \mathrm{~g}$ of fat, $30.9 \mathrm{~g}$ of protein and $16.2 \mathrm{~g}$ of fibre. Powder samples made from the seed and skin dried using different drying methods showed almost similar values as shown in Table 1. This could be due to the higher water content in the seed kernel which is protected by the seed shell (Joshi et al., 1993). Pumpkin powder produced from the flesh showed great hygroscopic property due to a higher sugar content $(4.36 / 100 \mathrm{~g})$ in the sample (Seroczyńska et al., 2014). All sample results show water activity of below 0.6 , indicating they are microbiologically safe (Quek et al., 2007).

\subsubsection{Physical properties}

As stated in Table 2, different drying methods showed significant effects $(p<0.05)$ on the particle size of sample powder made from different parts of pumpkin fruit except for pumpkin seed powder. In this study, oven drying method resulted in the smallest particle size while freeze-drying method yielded the biggest particle size of powder samples. Rapid hot air-dried pumpkin powder had a smaller particle size compared to freeze-dried pumpkin powder. The large particle size obtained in freeze-dried powder samples was due to the higher moisture content of the sample. As observed in Table 1, the highest final moisture content was shown in powder samples made from all parts of pumpkin fruit dried through freeze-drying method. The particle size reduction is affected by the friability of the materials, which in turn dependent upon the moisture content. In general, higher moisture content resulted in larger particle size. This is evident in all samples except for seed powder.

Table 1. Moisture properties of pumpkin powder made from different parts of the fruit with different drying methods

\begin{tabular}{cccc}
\hline \multirow{2}{*}{ Drying method } & Sample & \multicolumn{2}{c}{ Moisture properties } \\
\cline { 2 - 4 } & Skin & Moisture content (\%) & Water activity \\
\hline \multirow{2}{*}{ Oven } & Flesh & $6.58 \pm 0.03^{\mathrm{C}}$ & $0.315 \pm 0.005^{\mathrm{C}}$ \\
& Seed & $5.69 \pm 0.04^{\mathrm{C}}$ & $0.385 \pm 0.002^{\mathrm{C}}$ \\
& Unpeeled (Skin + Flesh) & $5.64 \pm 0.02^{\mathrm{C}}$ & $0.355 \pm 0.003^{\mathrm{C}}$ \\
\hline \multirow{3}{*}{ Rapid Hot Air } & Skin & $5.77 \pm 0.03^{\mathrm{B}}$ & $0.333 \pm 0.004^{\mathrm{B}}$ \\
& Flesh & $6.89 \pm 0.07^{\mathrm{B}}$ & $0.403 \pm 0.006^{\mathrm{B}}$ \\
& Seed & $5.61 \pm 0.04^{\mathrm{B}}$ & $0.325 \pm 0.003^{\mathrm{B}}$ \\
& Unpeeled (Skin + Flesh) & $5.89 \pm 0.02^{\mathrm{B}}$ & $0.373 \pm 0.003^{\mathrm{B}}$ \\
\hline \multirow{2}{*}{ Freeze } & Skin & $6.19 \pm 0.02^{\mathrm{A}}$ & $0.458 \pm 0.007^{\mathrm{A}}$ \\
& Flesh & $7.89 \pm 0.04^{\mathrm{A}}$ & $0.496 \pm 0.004^{\mathrm{A}}$ \\
& Seed & $6.04 \pm 0.04^{\mathrm{A}}$ & $0.421 \pm 0.004^{\mathrm{A}}$ \\
& Unpeeled (Skin + Flesh) & $6.73 \pm 0.06^{\mathrm{A}}$ & $0.473 \pm 0.004^{\mathrm{A}}$ \\
\hline
\end{tabular}

Values are expressed as mean \pm standard error. Values with different superscript within the row are significantly different $(\mathrm{p}<0.05)$. 
It has been observed in this study that the drying methods had significantly influenced $(p<0.05)$ the density properties of the powder in all pre-treatments except pumpkin seed powder samples. The lower density in the freeze-dried powder was due to the higher amount of moisture content in the powder compared to the oven and rapid hot air-dried powder hence producing larger particle size in the powder which creates more open structures. This results in the production of more void spaces between the powders which in turn lowers the powder density (Goula, 2005). A similar observation was reported where the density of ginger powder was affected by different particle sizes (Xiaoyan, 2008). The pumpkin skin powder samples showed the largest powder densities $\left(509.89-770.67 \mathrm{~kg} / \mathrm{m}^{3}\right)$ in the oven and rapid hot air-drying methods with the exclusion of the freeze-dried samples. The effect of different drying methods was not significant $(p>0.05)$ on the pumpkin seed powder samples, and this is due to the highest fat content in the seed powder.

Carr Index is a measurement of flow property and flowability of the powder is considered in processes concerning storage in silos and hoppers, transportation, formulation, mixing, and packaging (Knowlton et al., 1994). Table 2 shows Carr index range of sample powders made from different parts of the pumpkin fruit (19.49-33.81), where the data indicates that powder flowability ranges between fair to very poor (Lebrun et al., 2012). Good flowability values (fair to poor range) were obtained from powders made from unpeeled pumpkin and pumpkin flesh in all drying methods (19.49
-26.01). It is found that most powders with bigger particles have better flowability compared to powders with smaller particles as can be seen in Table 2 except for seed powder.

\subsubsection{Colour properties}

Different drying methods and processing conditions are found to affect the colour properties of the product as shown in Table 3. The colour properties were significantly affected $(p<0.05)$ by each drying method for all samples made from different parts of the pumpkin. Lightness $\left(\mathrm{L}^{*}\right)$ value yielded from the freeze-dried powder was the highest, followed by rapid hot air-dried and oven-dried powders, respectively. Freeze-dried powder samples showed the highest lightness value (55.67-64.37) followed by rapid hot air-dried powder samples (53.23-62.07). The oven-dried powder was found to have a lower lightness value ranging from 47.13 to 52.63. The low Lightness ( $\mathrm{L}^{*}$ ) value obtained can be explained by the longer drying time in the oven drying method which causes thermal degradation $\left(80^{\circ} \mathrm{C}\right)$. Danso -Boateng (2013) reported that basil leaves lose protein (about 89\%) due to the longer drying time at a temperature of $28^{\circ} \mathrm{C}$. The dark colour in the oven-dried powder can be characterized by browning reaction or Maillard reaction caused by the chemical reaction between sugar and protein (Malec et al., 2002). Maillard reaction causes colour degradation of products by the formation of a dark-brown polymeric compound named melanoidins (Kim and Lee, 2008a). It can be observed that oven-dried powder shows a darker colour with

Table 2. Physical properties of pumpkin powder made from different parts of the fruit with different drying methods

\begin{tabular}{ccccc}
\hline \multirow{2}{*}{ Sample } & Physical properties & Drying method \\
\cline { 3 - 5 } & Bulk density $\left(\mathrm{kg} / \mathrm{m}^{3}\right)$ & $532.05 \pm 8.26^{\mathrm{A}}$ & $248.37 \pm 3.50^{\mathrm{C}}$ & $509.89 \pm 15.14^{\mathrm{B}}$ \\
\cline { 3 - 5 } Skin & Tapped density $\left(\mathrm{kg} / \mathrm{m}^{3}\right)$ & $770.67 \pm 0.06^{\mathrm{A}}$ & $319.74 \pm 5.86^{\mathrm{C}}$ & $724.69 \pm 15.18^{\mathrm{B}}$ \\
& Particle size $(\mu \mathrm{m})$ & $114.00 \pm 0.32^{\mathrm{C}}$ & $140.57 \pm 0.53^{\mathrm{A}}$ & $122.98 \pm 1.04^{\mathrm{B}}$ \\
& Carr Index & $30.96 \pm 1.07^{\mathrm{A}}$ & $22.30 \pm 2.20^{\mathrm{B}}$ & $29.06 \pm 1.63^{\mathrm{A}}$ \\
\hline \multirow{3}{*}{ Flesh } & Bulk density $\left(\mathrm{kg} / \mathrm{m}^{3}\right)$ & $466.15 \pm 10.81^{\mathrm{A}}$ & $215.47 \pm 2.35^{\mathrm{C}}$ & $349.31 \pm 7.06^{\mathrm{B}}$ \\
& Tapped density $\left(\mathrm{kg} / \mathrm{m}^{3}\right)$ & $630.08 \pm 24.03^{\mathrm{A}}$ & $275.75 \pm 4.39^{\mathrm{C}}$ & $458.49 \pm 6.10^{\mathrm{B}}$ \\
& Particle size $(\mu \mathrm{m})$ & $128.76 \pm 0.88^{\mathrm{C}}$ & $145.19 \pm 0.55^{\mathrm{A}}$ & $135.11 \pm 0.49^{\mathrm{B}}$ \\
& Carr Index & $26.01 \pm 1.91^{\mathrm{A}}$ & $21.85 \pm 0.66^{\mathrm{B}}$ & $23.81 \pm 2.34^{\mathrm{AB}}$ \\
\hline \multirow{3}{*}{ Seed } & Bulk density $\left(\mathrm{kg} / \mathrm{m}^{3}\right)$ & $335.60 \pm 3.29^{\mathrm{A}}$ & $299.20 \pm 4.50^{\mathrm{B}}$ & $304.80 \pm 2.70^{\mathrm{B}}$ \\
& Tapped density $\left(\mathrm{kg} / \mathrm{m}^{3}\right)$ & $473.03 \pm 6.39^{\mathrm{A}}$ & $452.15 \pm 5.83^{\mathrm{B}}$ & $438.32 \pm 5.55^{\mathrm{C}}$ \\
& Particle size $(\mu \mathrm{m})$ & $215.29 \pm 3.31^{\mathrm{B}}$ & $252.64 \pm 5.76^{\mathrm{A}}$ & $256.46 \pm 2.26^{\mathrm{A}}$ \\
& Carr Index & $29.05 \pm 0.86^{\mathrm{B}}$ & $33.81 \pm 1.79^{\mathrm{A}}$ & $30.45 \pm 1.30^{\mathrm{B}}$ \\
\hline \multirow{2}{*}{ Unpeeled } & Tapped density $\left(\mathrm{kg} / \mathrm{m}^{3}\right)$ & $640.42 \pm 11.68^{\mathrm{A}}$ & $283.60 \pm 4.63^{\mathrm{C}}$ & $484.48 \pm 13.72^{\mathrm{B}}$ \\
Flesh) & Particle size $(\mu \mathrm{m})$ & $120.89 \pm 0.30^{\mathrm{C}}$ & $141.71 \pm 0.30^{\mathrm{A}}$ & $129.55 \pm 2.59^{\mathrm{B}}$ \\
& Bulk density $\left(\mathrm{kg} / \mathrm{m}^{3}\right)$ & $485.63 \pm 13.83^{\mathrm{A}}$ & $220.99 \pm 2.83^{\mathrm{C}}$ & $390.03 \pm 8.86^{\mathrm{B}}$ \\
& Carr Index & $24.17 \pm 1.87^{\mathrm{A}}$ & $22.07 \pm 0.28^{\mathrm{AB}}$ & $19.49 \pm 0.45^{\mathrm{B}}$ \\
\hline
\end{tabular}

Values are expressed as mean \pm standard error. Values with different superscript within the row are significantly different $(\mathrm{p}<0.05)$. 
Table 3. Colour properties of pumpkin powder made from different parts of the fruit with different drying methods

\begin{tabular}{ccccc}
\hline \multirow{2}{*}{$\begin{array}{c}\text { Drying } \\
\text { method }\end{array}$} & Sample & \multicolumn{3}{c}{ Colour properties } \\
\cline { 3 - 5 } Fresh & Skin & $56.00 \pm 0.78^{\mathrm{C}}$ & $6.57 \pm 0.21^{\mathrm{D}}$ & Lellowness $\left(\mathrm{b}^{*}\right)$ \\
& Flesh & $55.03 \pm 0.60^{\mathrm{C}}$ & $11.40 \pm 0.17^{\mathrm{D}}$ & $49.67 \pm 0.42^{\mathrm{D}}$ \\
& Seed & $60.27 \pm 0.55^{\mathrm{A}}$ & $3.23 \pm 0.12^{\mathrm{D}}$ & $30.97 \pm 0.58^{\mathrm{D}}$ \\
\hline \multirow{4}{*}{ Oven } & Skin & $48.27 \pm 0.25^{\mathrm{D}}$ & $15.00 \pm 0.36^{\mathrm{A}}$ & $48.70 \pm 0.36^{\mathrm{A}}$ \\
& Flesh & $47.13 \pm 0.06^{\mathrm{D}}$ & $17.70 \pm 0.30^{\mathrm{A}}$ & $58.67 \pm 0.35^{\mathrm{A}}$ \\
& Seed & $52.63 \pm 0.25^{\mathrm{D}}$ & $5.80 \pm 0.26^{\mathrm{A}}$ & $33.97 \pm 0.42^{\mathrm{A}}$ \\
\hline \multirow{2}{*}{ Rapid Hot } & Skin & $62.07 \pm 0.40^{\mathrm{B}}$ & $13.43 \pm 0.40^{\mathrm{B}}$ & $45.57 \pm 1.27^{\mathrm{B}}$ \\
Air & Flesh & $61.27 \pm 0.06^{\mathrm{B}}$ & $16.53 \pm 0.47^{\mathrm{B}}$ & $56.77 \pm 0.21^{\mathrm{B}}$ \\
& Seed & $53.23 \pm 0.76^{\mathrm{C}}$ & $5.03 \pm 0.12^{\mathrm{B}}$ & $33.07 \pm 0.36^{\mathrm{B}}$ \\
\hline \multirow{3}{*}{ Freeze } & Skin & $64.37 \pm 0.32^{\mathrm{A}}$ & $7.43 \pm 0.12^{\mathrm{C}}$ & $44.87 \pm 0.51^{\mathrm{C}}$ \\
& Flesh & $63.40 \pm 0.17^{\mathrm{A}}$ & $13.43 \pm 0.40^{\mathrm{C}}$ & $50.77 \pm 0.61^{\mathrm{C}}$ \\
& Seed & $55.67 \pm 0.35^{\mathrm{B}}$ & $4.50 \pm 0.10^{\mathrm{C}}$ & $31.20 \pm 0.53^{\mathrm{C}}$ \\
\hline
\end{tabular}

Values are expressed as mean \pm standard error. Values with different superscript within the row are significantly different $(\mathrm{p}<0.05)$.

highest $\mathrm{a}^{*}(4.90-17.70)$ and $\mathrm{b}^{*}(33.07-58.67)$ values followed by rapid hot air-dried powder $\left(\mathrm{a}^{*}=4.33-16.53\right.$, $\left.\mathrm{b}^{*}=29.93-56.77\right)$ and freeze-dried powder $\left(\mathrm{a}^{*}=4.31\right.$ $\left.13.43, b^{*}=29.27-50.76\right)$. All powder samples made from different parts of pumpkin fruit dried using the rapid hot air-drying method exhibit a higher lightness value compared to the oven-dried pumpkin powder (made from all parts of pumpkin fruit). This is due to the shorter drying duration of the rapid hot air drying method ( 1 hour 45 mins and $2 \mathrm{hrs} 45$ mins) compared to the oven drying method (15 hrs and $30 \mathrm{hrs}$ ) which can prevent the product from thermal degradation. The findings in line with the study carried out by Nawirska et al. (2009).

An increase in the $\Delta \mathrm{E}$ value indicates an increase in colour change which occurs during the drying process (Figure 1). During drying, the redness (a*) and yellowness $\left(b^{*}\right)$ values will be affected. This is because both redness $\left(\mathrm{a}^{*}\right)$ and yellowness $\left(\mathrm{b}^{*}\right)$ values are dependent on the lightness $\left(\mathrm{L}^{*}\right)$ value which can be higher due to the drying effect. According to Yusof et al., (2012) colour change is based upon the $\mathrm{L}^{*}, \mathrm{a}^{*}$ and $\mathrm{b}^{*}$ values. The oven-dried powder shows a total change of colour value between 8.36 and 13.58 , the freeze-dried powder was between 4.86 and 8.87 , whereas rapid hot air -dried powder yields values between 7.54 and 10.86. Oven-dried pumpkin flesh powder showed the highest total colour change (13.58), while the lowest colour change was observed in freeze-dried seed powder (4.86). Similar results were obtained by Henriques et al. (2012), who reported that freeze-dried pumpkin had lower total colour change (8.21) compared to pumpkin samples when dried using chamber and tunnel drying methods.

\subsubsection{Chemical properties}

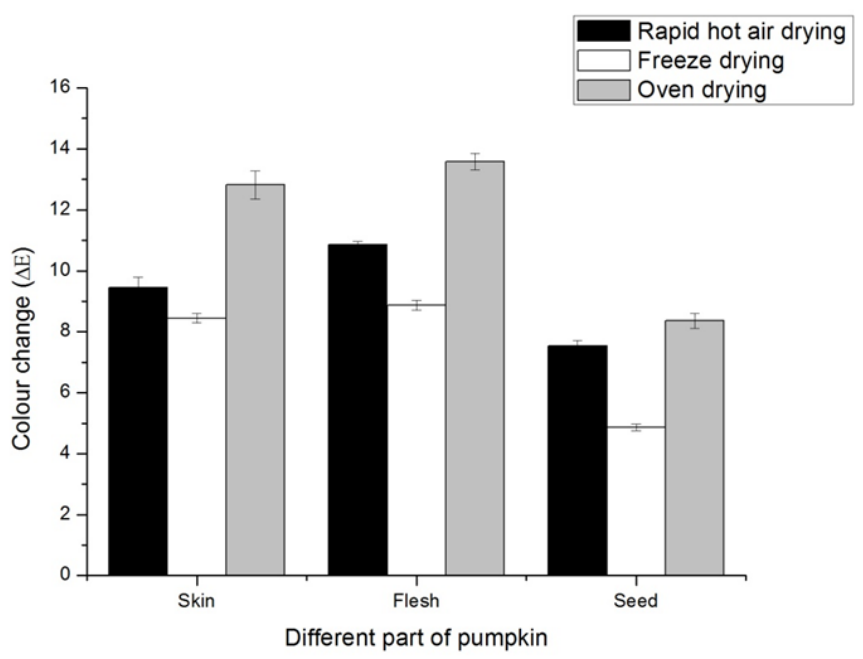

Figure 1. Colour change of pumpkin powder made from different parts of the fruit with different drying methods

The proximate composition of the powder was significantly affected by the drying methods $(p<0.05)$ except for fibre content. Pumpkin flesh powder processed through oven drying and rapid hot air-drying methods lose more protein content compared to powder processed through the freeze-drying method. This is due to the denaturing of proteins which can occur during drying. According to Abioye et al. (2014) and Davis, (2015), heat applied during drying can cause the weakening of the three-dimensional conformation of the protein cells, consequently leading to the loss of protein. The heat was also found to reduce nutrient value in dried tomatoes samples (Ladan et al., 1997). The rapid hot airdrying method showed a higher protein content (9.86$31.54 \%$ ) than the oven drying method (8.60-30.03\%), and this is due to the shorter drying time compared to the oven drying method.

High temperatures utilized in the oven and rapid hot air-drying methods $\left(80^{\circ} \mathrm{C}\right)$ was found to have a lower fat 
content compared to the freeze-drying method, which was operated at a low temperature $\left(-110^{\circ} \mathrm{C}\right)$. The powder samples made from different parts of pumpkin resulted in the lowest fat content in samples dried with the ovenand rapid hot air-drying methods (3.68-34.93\%), while the highest fat content was obtained for freeze-dried samples (4.18-36.77\%). A decrease in the fat content of powder samples made from all parts of pumpkin observed in this study was hypothesised to be caused by lipid oxidation. Heat, light and radiation are known to increase the oxidation rate (Savage et al., 2002).

The fibre content in all powder samples was not significantly influenced by drying methods $(\mathrm{p}>0.05)$. This result is in accordance with the study by Hsu et al. (2003), Mepba et al. (2007) and Mbah et al. (2012), who found that fibre content was not significantly affected ( $>0.05$ ) by drying.

The ash content of pumpkin powder was significantly $(p<0.05)$ affected by the drying methods where freeze-dried powder showed a higher ash content (5.29-13.35\%) compared to oven-dried and rapid hot airdried pumpkin powders respectively. High values of ash content are indicative of high mineral content (e.g. macrominerals) in the pumpkin powder (Adeleke and Odedeji, 2010; Okareh et al., 2015). The high value of ash content yielded from freeze-dried samples is a result of the freeze-drying process that was able to minimise the negative effects of high-temperature exposure. In addition, the freeze-drying method can also preserve colour, flavour, texture, nutrients, taste, appearance and chemical composition (Nawirska et al., 2009; Laokuldilok and Kanha, 2015).

The carbohydrate content ranges from $10.32 \%$ to $74.74 \%, 5.45 \%$ to $72.15 \%$ and $3.81 \%$ to $69.35 \%$ for oven-dried, rapid hot air-dried and freeze-dried pumpkin powders, respectively (Table 4). It was found that different drying methods significantly affected $(p<0.05)$ the carbohydrate content of powder samples as it was related to the moisture content, protein, fibre, fat and ash values. The lowest carbohydrate content (3.81-10.32\%) was obtained from pumpkin seed powder samples. This may be due to the role of the seed shell's protecting the kernel from nutrient loss (Joshi et al., 1993).

\section{Conclusion}

In conclusion, different drying methods show a significant effect $(p<0.05)$ on powder samples made from different parts of pumpkin fruit. The rapid hot airdrying method resulted in positive effects on the powder properties, such as moisture properties, physical properties (particle size, densities and flowability), colour properties and proximate composition for all types of powder.

\section{Conflict of interest}

The authors declare no conflict of interest.

\section{Acknowledgments}

The author would like to thank UPM for its support

Table 4. Proximate composition of pumpkin powder made from different parts of the fruit with different drying methods

\begin{tabular}{|c|c|c|c|c|c|c|c|}
\hline \multirow{2}{*}{$\begin{array}{l}\text { Drying } \\
\text { method }\end{array}$} & \multirow{2}{*}{ Sample } & \multicolumn{6}{|c|}{ Components (Dry basis \%) } \\
\hline & & Moisture (\%) & Protein (\%) & Fibre (\%) & Fat (\%) & Ash (\%) & Carbohydrate (\%) \\
\hline \multirow{4}{*}{ Fresh } & Skin & $406.33 \pm 1.18^{\mathrm{C}}$ & $26.13 \pm 0.08^{\mathrm{E}}$ & $11.79 \pm 0.24^{\mathrm{B}}$ & $6.03 \pm 0.07^{\mathrm{E}}$ & $14.79 \pm 0.02^{\mathrm{B}}$ & $45.57 \pm 1.38^{\mathrm{K}}$ \\
\hline & Flesh & $668.64 \pm 0.08^{\mathrm{A}}$ & $16.99 \pm 0.16^{\mathrm{H}}$ & $4.39 \pm 0.01^{\mathrm{D}}$ & $4.57 \pm 0.03^{\mathrm{J}}$ & $13.36 \pm 0.30^{\mathrm{C}}$ & $69.02 \pm 0.32^{\mathrm{CD}}$ \\
\hline & Seed & $71.47 \pm 0.28^{\mathrm{D}}$ & $34.32 \pm 0.35^{\mathrm{A}}$ & $23.26 \pm 0.63^{\mathrm{A}}$ & $38.89 \pm 0.22^{\mathrm{A}}$ & $6.81 \pm 0.03^{\mathrm{K}}$ & $2.12 \pm 0.28^{\mathrm{O}}$ \\
\hline & Unpeeled & $523.44 \pm 0.08^{\mathrm{B}}$ & $20.69 \pm 0.46^{\mathrm{F}}$ & $8.73 \pm 0.22^{\mathrm{C}}$ & $5.76 \pm 0.05^{\mathrm{FG}}$ & $15.13 \pm 0.12^{\mathrm{A}}$ & $49.06 \pm 0.37^{\mathrm{J}}$ \\
\hline \multirow{4}{*}{ Oven } & Skin & $5.78 \pm 0.09^{\mathrm{L}}$ & $14.55 \pm 0.36^{\mathrm{J}}$ & $11.70 \pm 0.06^{\mathrm{B}}$ & $4.96 \pm 0.17^{\mathrm{HI}}$ & $9.75 \pm 0.05^{\mathrm{J}}$ & $59.03 \pm 0.63^{\mathrm{F}}$ \\
\hline & Flesh & $7.00 \pm 0.17^{\mathrm{G}}$ & $8.60 \pm 0.03^{\mathrm{MN}}$ & $4.36 \pm 0.12^{\mathrm{D}}$ & $3.68 \pm 0.15^{\mathrm{M}}$ & $8.62 \pm 0.07^{\mathrm{JK}}$ & $74.74 \pm 0.22^{\mathrm{A}}$ \\
\hline & Seed & $5.63 \pm 0.06^{\mathrm{M}}$ & $30.03 \pm 0.61^{\mathrm{D}}$ & $23.17 \pm 0.27^{\mathrm{A}}$ & $32.54 \pm 0.70^{\mathrm{D}}$ & $4.04 \pm 0.20^{\mathrm{N}}$ & $10.32 \pm 1.44^{\mathrm{L}}$ \\
\hline & Unpeeled & $5.85 \pm 0.03^{\mathrm{KL}}$ & $12.00 \pm 0.06$ & $8.56 \pm 0.09^{\mathrm{C}}$ & $4.74 \pm 0.09^{\mathrm{IJ}}$ & $11.46 \pm 0.27^{\mathrm{G}}$ & $63.22 \pm 0.34^{\mathrm{D}}$ \\
\hline \multirow{4}{*}{$\begin{array}{c}\text { Rapid Hot } \\
\text { Air }\end{array}$} & Skin & $6.04 \pm 0.17^{\mathrm{J}}$ & $16.32 \pm 0.06^{\mathrm{HI}}$ & $11.71 \pm 0.22^{\mathrm{B}}$ & $5.34 \pm 0.11^{\mathrm{G}}$ & $11.17 \pm 0.01^{\mathrm{H}}$ & $55.46 \pm 0.46^{\mathrm{H}}$ \\
\hline & Flesh & $7.30 \pm 0.17^{\mathrm{F}}$ & $9.86 \pm 0.23^{\mathrm{M}}$ & $4.36 \pm 0.04^{\mathrm{D}}$ & $3.88 \pm 0.08^{\mathrm{L}}$ & $10.13 \pm 0.13^{\mathrm{I}}$ & $72.15 \pm 0.13^{\mathrm{B}}$ \\
\hline & Seed & $5.89 \pm 0.21^{\mathrm{K}}$ & $31.94 \pm 0.12^{\mathrm{C}}$ & $23.15 \pm 0.20^{\mathrm{A}}$ & $34.93 \pm 0.50^{\mathrm{C}}$ & $4.54 \pm 0.02^{\mathrm{M}}$ & $5.45 \pm 0.76^{\mathrm{M}}$ \\
\hline & Unpeeled & $6.33 \pm 0.09^{\mathrm{I}}$ & $13.95 \pm 0.10^{\mathrm{K}}$ & $8.61 \pm 0.10^{\mathrm{C}}$ & $4.85 \pm 0.06^{\mathrm{I}}$ & $12.09 \pm 0.07^{\mathrm{E}}$ & $60.50 \pm 0.19^{\mathrm{E}}$ \\
\hline \multirow{4}{*}{ Freeze } & Skin & $6.52 \pm 0.19^{\mathrm{H}}$ & $17.31 \pm 0.12^{\mathrm{G}}$ & $11.79 \pm 0.51^{\mathrm{B}}$ & $5.78 \pm 0.27^{\mathrm{F}}$ & $12.03 \pm 0.05^{\mathrm{EF}}$ & $53.09 \pm 0.50^{\mathrm{HI}}$ \\
\hline & Flesh & $8.61 \pm 0.06^{\mathrm{E}}$ & $11.31 \pm 0.10^{\mathrm{L}}$ & $4.42 \pm 0.19^{\mathrm{D}}$ & $4.18 \pm 0.14^{\mathrm{K}}$ & $11.74 \pm 0.08^{\mathrm{F}}$ & $69.35 \pm 0.38^{\mathrm{C}}$ \\
\hline & Seed & $6.48 \pm 0.08^{\mathrm{HI}}$ & $33.85 \pm 0.02^{\mathrm{B}}$ & $23.28 \pm 0.10^{\mathrm{A}}$ & $36.77 \pm 0.05^{\mathrm{B}}$ & $5.29 \pm 0.03^{\mathrm{L}}$ & $3.81 \pm 0.04^{\mathrm{N}}$ \\
\hline & Unpeeled & $7.24 \pm 0.08^{\mathrm{FG}}$ & $15.56 \pm 0.14^{\mathrm{I}}$ & $8.69 \pm 0.17^{\mathrm{C}}$ & $5.06 \pm 0.26^{\mathrm{H}}$ & $13.35 \pm 0.06^{\mathrm{D}}$ & $57.33 \pm 0.51^{\mathrm{G}}$ \\
\hline
\end{tabular}

Values are expressed as mean \pm standard error. Values with different superscript within the row are significantly different $(\mathrm{p}<0.05)$. 
in this project.

\section{References}

Abioye, V.F., Adejuyitan, J.A. and Idowu, C.F. (2014). Effects of different drying methods on the nutritional and quality attributes of baobab leaves (Adansonia digitata). Agriculture and Biology Journal of North America, 5(3), 104-108.

Adeleke, R.O. and Odedeji, J.O. (2010). Acceptability studies on bread fortified with tilapia fish flour. Pakistan Journal of Nutrition, 9(6), 531-534. https:// doi.org/10.3923/pjn.2010.531.534

Amidon, G.E., Secreast, P.J. and Mudie, D. (2009). Chapter 8- Particle, powder and compact characterization. In Qiu, Y., Chen, Y., Zhang, G.G.Z., Liu, L. and Porter, W.R. (Eds.) Developing Solid Oral Dosage Forms. Pharmaceutical Theory and Practice, p. 163-186. Diego: Academic Press. https://doi.org/10.1016/B978-0-444-53242-8.000084

AOAC. (2000). Official methods of analysis of AOAC International. Vol. 2. Washington, DC, USA: Association of Official Analytical Chemists.

Danso-Boateng, E. (2013). Effect of drying methods on nutrient quality of Basil (Ocimum viride) leaves cultivated in Ghana. International Food Research Journal, 20(4), 1569-1573.

Davis, S. (2015). The effects of heat on protein food. Retrieved on 19 September 2016 from Livestrong website: http://www.livestrong.com/article/59858effects-protein-heated/

Doymaz, I. (2007). The kinetics of forced convective airdrying of pumpkin slices. Journal of Food Engineering, 79(1), 243-248. https:// doi.org/10.1016/j.jfoodeng.2006.01.049

Goula, A. (2005). Spray drying of tomato pulp in dehumidified air: II. The effect on powder properties. Journal of Food Engineering, 66(1), 3542. https://doi.org/10.1016/j.jfoodeng.2004.02.031

Hsu, C.L., Chen, W., Weng, Y.M. and Tseng, C.Y. (2003). Chemical composition, physical properties and antioxidant activities of yam flours as affected by different drying methods. Food Chemistry, 83(1), 85-92. https://doi.org/10.1016/S0308-8146(03)00053 $-0$

Intipunya, P. and Bhandari, R. (2010). 22 - Chemical deterioration and physical instability of food and beverages. In Skibsted, L.H., Risbo, J. and Andersen, M.L. (Eds.). Chemical Deterioration and Physical Instability of Food and Beverages. USA: Woodhead Publishing Limited. https:// doi.org/10.1533/9781845699260.3.663

Jinapong, N., Suphantharika, M. and Jamnong, P.
(2008). Production of instant soymilk powders by ultrafiltration, spray drying and fluidized bed agglomeration. Journal of Food Engineering, 84(2), 194-205. https://doi.org/10.1016/ j.jfoodeng.2007.04.032

Joshi, D.C., Das, S.K. and Mukherjee, R.K. (1993). Physical properties of pumpkin seeds. Journal of Agricultural Engineering Research, 54(3), 219-229. https://doi.org/10.1006/jaer.1993.1016

Jun, H., Lee, C.H., Song, G.S. and Kim, Y.S. (2006). Characterization of the pectin polysaccharides from pumpkin peel. Journal of Food Science and Technology, 39, 554-561. https://doi.org/10.1016/ j.lwt.2005.03.004

Knowlton, T.M., Carson, J.W., Klinzing, G.E. and Yang, W.C. (1994). The importance of storage, transfer and collection. Chemical Engineering Progress, 90, 4454.

Kim, J.S. and Lee, Y.S. (2008a). Effect of $\mathrm{pH}$ on the enolization of sugars and antioxidant activity of caramelisation browning. Food Science and Biotechnology, 17(5), 931-939.

Kim, M.Y., Kim, E.J., Kim, Y.N., Choi, C. and Lee, B.H. (2012). Comparison of the chemical compositions and nutritive values of various pumpkin (Cucurbitaceae) species and parts. Journal of Nutrition Research and Practice, 6(1), 21-27. https://doi.org/10.4162/nrp.2012.6.1.21

Ladan, M.J., Abubakar, M.G. and Lawal, M. (1997). Effect of solar drying on the nutrient composition of tomatoes. Nigeria Journal of Renewable Energy, 5, 67-69.

Laokuldilok, T. and Kanha, N. (2015). Effects of processing conditions on powder properties of black glutinous rice (Oryza sativa L.) bran anthocyanins produced by spray drying and freeze-drying. $L W T$ Food Science and Technology, 64(1), 405-411. https://doi.org/10.1016/j.lwt.2015.05.015

Lebrun, P., Krier, F., Mantanus, J., Grohganz, H., Yang, M., Rozet, E. and Hubert, P. (2012). Design space approach in the optimization of the spray-drying process. European Journal of Pharmaceutics and Biopharmaceutics, 80(1), 226-234. https:// doi.org/10.1016/j.ejpb.2011.09.014

Lee, H.A., Lee, S.S., and Shin, H.K. (1997). Effect of apple dietary fiber on the in vitro growth of intestinal bacteria. Korean Journal of Food Science and Technology, 29(1), 107-114.

Lin, L., Lei, F., Sun, D., Dong, Y., Yang, B. and Zhao, M. (2012). Thermal inactivation kinetics of Rbdosia serra Hara leaf peroxidase and polyphenol oxidase and comparative evaluation of drying methods on 
leaf phenolic profile and bioactivities. Food Chemistry, 134(4), 2021-2029. https:// doi.org/10.1016/j.foodchem.2012.04.008

Malec, L.S., Gonzales, A.S.P., Naranjo, G.B. and Vigo, M.S. (2002). Influence of water activity and storage temperature on lysine availability of a milk like system. Food Research International, 35(9), 849853. https://doi.org/10.1016/S0963-9969(02)00088-1

Mbah, B.O., Eme, P.E. and Paul, A.E. (2012). Effect of drying techniques on the proximate and other nutrient composition of Moringa oleifera leaves from two areas in eastern Nigeria. Pakistan Journal of Nutrition, 11(11), 1044-1048. https:// doi.org/10.3923/pjn.2012.1044.1048

Mepba, H.D., Eboh, L. and Banigo, D.E.B. (2007). Effects of processing treatments on the nutritive composition and consumer acceptance of some Nigerian edible leafy vegetable. African Journal of Food Agriculture Nutrition and Development, 7, 118.

Nawirska, A., Figiel, A., Kucharska, A.Z., Letowska, A.S. and Biesiada, A. (2009). Drying kinectics and quality parameters of pumpkin slices dehydrated using different methods. Journal of Food Engineering, 94(1), 14-20. https://doi.org/10.1016/ j.jfoodeng.2009.02.025

Norfezah, M.N., Hardacre, A. and Brennan, C.S. (2010). Comparison of waste pumpkin material and its potential use in extruded snack foods. Food Science and Technology International, 17(4), 367-373. https://doi.org/10.1177/1082013210382484

Norshazila, S., Irwandi, J., Othman, R. and Zuhanis, H.H.Y. (2014). Carotenoid content in different locality of pumpkin (Cucurbita moschata) in Malaysia. International Journal of Pharmacy and Pharmaceutical Sciences, 6(3), 29-32.

Okareh, O.T., Adeolu, A.T. and Adepoju, O.T. (2015). Proximate and mineral composition of plantain (Musa Paradisiaca) wastes flour; a potential nutrients source in the formation of animal feeds. African Journal of Food Science and Technology, 6(2), 5357. https://doi.org/10.14303/ajfst.2015.015

Quek, S.Y., Chok, N.K. and Swedlund, P. (2007). The physicochemical properties of spray dried watermelon powders. Chemical Engineering and Processing, 46(5), 386-392. https://doi.org/10.1016/ j.cep. 2006.06 .020

Şahin-Nadeem, H., Dinçer, C., Torun, M., Topuz, A. and Özdemir, F. (2013). Influence of inlet air temperature and carrier material on the production of instant soluble sage (Salvia fruticosa Miller) by spray drying. LWT-Food Science and Technology,
52(1), 31-38.

https://doi.org/10.1016/

j.lwt.2013.01.007

Saohin, W., Boonchong, P., Lamlikitkuakoon, S., Jamnoiprom, I. and Mungdee, W. (2007). Effects of drying temperature and residual moisture content of Fa-Tha-Li (Andrographis paniculate (Burm.f.) Nees) crude powder for capsule preparation. Thai Journal of Pharmaceutical Science, 31, 28-35.

Savage, G.P., Dutta, P.C. and Rodriguez-Estrada, M.T. (2002). Cholesterol oxides: their occurrence and methods to prevent their generation in foods. Asia Pacific Journal of Clinical Nutrition, 11(1), 72-78. https://doi.org/10.1046/j.1440-6047.2002.00270.x

See, E.F., Nadiah, W.A.W. and Aziah, A.A.N. (2007). Physico-chemical and sensory evaluation of breads supplemented with pumpkin flour. ASEAN Food Journal, 14(2), 123-130.

Seroczyńska, A., Antczak, A., Korytowska, M., Kamińska, K., Radomski, A., Korzeniewska, A., Zawadzki, J. and Niemirowicz-szczytt, K. (2014). Evaluation of the selected forms of winter squash (Cucurbita maxima Duch.) for the content of free sugars and polysaccharides. Polish Journal of Agronomy, 16, 69-73.

Tze, N.L., Han, C.P., Yusof, Y.A., Ling, C.N., Talib, R.A., Taip, F.S. and Aziz, M.G. (2012). Physicochemical and nutritional properties of spraydried pitaya fruit powder as natural colorant. Journal of Food Science and Biotechnology, 21(3), 675-682. https://doi.org/10.1007/s10068-012-0088-Z

Xiaoyan, Z.Y. (2008). Effect of superfine grinding on properties of ginger powder. Journal of Food Engineering, 91(2), 217-222. https:// doi.org/10.1016/j.jfoodeng.2008.08.024

Yusof, Y.A, Salleh, F.S.M., Chin, N.L. and Talib, R.A. (2012). The drying and tabletting of pitaya powder. Journal of Food Process Engineering, 35(5), 763771. https://doi.org/10.1111/j.1745- 